\title{
Forensic Genetics and Governance of Transnational Criminality
}

\begin{abstract}
Contemporary societies are increasingly facilitating movement while simultaneously creating forms of restricting and monitoring the mobility of persons deemed problematic. This chapter focuses on the growing relevance of genetic technologies in this domain by discussing the several forms whereby genetics has been used to prevent, manage and survey transnational criminality. In order to shed light on the complexities associated with such a phenomenon, we provide the reader with an indepth explanation of an empirical example: a pan-European network, called the Prüm system, created to exchange the data stored in the national DNA databases of different European Union (EU) countries in order to combat terrorism and cross-border criminality.
\end{abstract}

Keywords International mobility $\bullet$ Transnational criminality $\bullet$ Exchange of DNA data $\bullet$ Prüm system

\section{The Control of Irregular Mobility}

The celebration and facilitation of the movement of people, goods and capital within the European Union (EU) coexists with attempts to monitor, restrict or inhibit the mobility of individuals deemed problematic (Aas, 2013; Bigo, 2005; Pickering \& Weber, 2006). Although Europe's internal borders have been to a certain extent abolished, as pointed out by Dennis Broeders and Huub Dijstelbloem, "mobility is not for everyone:

(C) The Author(s) 2020 
there is a politics of mobility in which the differential distribution of mobility produces some of the starkest differences today" (Broeders \& Dijstelbloem, 2016, p. 245). As a result, surveillance systems are increasingly being deployed to work as instruments of social sorting (Lyon, 2007), segregating between "legitimate" and "illegitimate" mobilities (Amoore, 2006). Respectively, one kind of mobility is associated with high economic, cultural and social capital, regarding individuals moving due to leisure and/or business; while another kind of mobility is associated with irregular immigration and/or criminal practices (Aas, 2011). It is thereby clear that tracing mobility is no longer solely focused on territorial borders. The management of borders has shifted and expanded to a focus on internationally mobile populations that are considered as suspect communities (Aas, 2011; Ajana, 2013; Bosworth \& Guild, 2008; Broeders, 2007; Skinner, 2018; Tutton, Hauskeller, \& Sturdy, 2014). Such suspect communities are defined by the interlinking of nationality, race and (lack thereof of) social, cultural and economic power.

Transnational criminality tends to be approached as one of the most significant challenges posed by international mobility. As a result, at least in terms of public discourse, the prevention and investigation of crossborder crime have been the main driving force and justification for the proliferation of surveillance systems (Aas, 2011, p. 337). Nowadays, societies have been witnessing a swift development in the expansion of networks of surveillance systems and networked databases aimed at visualizing, registering, mapping, monitoring and profiling mobile populations defined in terms of risk (Broeders \& Dijstelbloem, 2016). Within such context, biometric technologies have been increasingly deployed as the prime form to control and manage international mobility (Aas, 2011). Biometric technologies create an inseparability between corporal and digital elements in contemporary governance projects (M'charek, Schramm, \& Skinner, 2014).

This chapter focuses on a EU system which clearly outlines the role of forensic genetics in the governance of crime: a pan-European network, called the Prüm system, created to exchange the data stored in the national databases of different EU countries in order to combat terrorism and cross-border criminality. Several policies aimed at crime control and migration directly or indirectly highlight and discriminate against minorities and populations or individuals originating from specific countries. Contrary to such a scenario, the Prüm system directly targets already criminalized populations, since it networks different forensic DNA databases. 


\section{Background and Rationale of the Prüm Decisions}

In the aftermath of Schengen, ${ }^{1}$ which abolished border controls in a number of European countries, several EU Member States became increasingly concerned about transnational movements of people deemed risky and, consequently, about the growth of transnational crime (Broeders, 2007; Guild \& Geyer, 2008; Hufnagel \& McCartney, 2017). Although the informal exchange of DNA data has often taken place on an ad hoc basis (Hufnagel \& McCartney, 2015; McCartney, Wilson, \& Williams, 2011), it was no longer deemed as sufficient and, consequently, voices began to be heard calling for a closer cooperation among police forces (Luif, 2007).

Attempting to respond to such perceived need to expand the transnational surveillance network and foster closer police cooperation, on May 2005, in the small German town of Prüm, the government representatives from Austria, Belgium, France, Luxembourg, Germany, the Netherlands and Spain signed a treaty that would become known as the Prüm Convention, ${ }^{2}$ which set provisions for exchanging data regarding DNA, fingerprints and motor vehicle information. The preamble of the Convention stated that, in the context of the free movement of persons, the EU Member States had to

[p]lay a pioneering role in establishing the highest possible standard of cooperation, especially by means of exchange of information, particularly in combating terrorism, cross-border crime and illegal migration, while leaving participation in such cooperation open to all other Member States in the European Union. (EU Council, 2005, p. 3)

The background leading to the Prüm Convention was an initiative by Otto Schily, the former Interior Minister of Germany who, in 2003, proposed a closer cooperation in justice and internal affairs with France, Belgium and Luxembourg in a context where a Police Centre was opened in Luxembourg by the four countries. According to Paul Luif (2007), this

\footnotetext{
${ }^{1}$ The Schengen acquis, in 1995, pertains to the abolition of border controls of a number of European countries. Subsequently, the Treaty of Amsterdam, in 1997, has adopted the Schengen agreement into EU law.

${ }^{2}$ In this chapter the authors use the term "Prüm Convention" to refer to the 2005 Convention involving seven countries, the term "Prüm Decision" to refer to the Council Decision that established the mandatory nature of transnational data exchange for all EU Member States and the term "Prüm system" to refer to the actual network of European Union countries exchanging DNA data.
} 
initiative, which aimed to develop a closer cooperation between the police forces of Germany and its neighbours, was deemed necessary because of "transnational crime, which had increased after removing the Iron curtain at the end of the Cold War and which had been made easier by the ceasing of border controls between the participants of the Schengen area" (Luif, 2007: 6; see also Bigo, 2004, 2008: 94; Bigo \& Guild, 2005; Kuus, 2004; M'charek et al., 2014: 16).

In 2008, some of the Prüm Convention provisions were subsumed into the police and judicial cooperation provisions in European Union law by a Council Decision, commonly referred to as the Prüm Decisions (EU Council, 2008a, 2008b). These Prüm Decisions made it mandatory for all EU Member States to join the pan-European network for the exchange of fingerprints, DNA profiles and motor vehicle information. It was decided that data should remain the property of the Member State where it was collected, eliminating the need for a centralized database. Therefore, this meant that all EU Member States that had yet to establish databases for DNA profiles, fingerprints and vehicle data information were obliged to do so, in order to allow access to them to the relevant EU authorities. August 2011 was the deadline established for all EU countries to comply with the Prüm Decisions. However, most countries were unable to comply with such a deadline due to several reasons (McCartney et al., 2011; Prainsack \& Toom, 2013): (1) difficulties faced in the mobilization of political majorities to adapt national laws to Prüm provisions; (2) conflicts between stakeholders over who should take responsibilities for Prüm; (3) human and financial resources (Prainsack \& Toom, 2013; Töpfer, 2011). Moreover, Italy, Greece, Ireland and Malta faced additional constraints as they did not have a DNA database or dedicated legislation when the Prüm Decisions were adopted (Toom, Granja, \& Ludwig, 2019).

Currently, the latest report on the progress of the implementation of Prüm on DNA data, dating from September 2019, indicates that there are 25 EU Member States in operational conditions (EU Council, 2019). The non-operational countries are Greece, Ireland and Italy. Being operational within Prüm's transnational exchange of DNA data does not, however, immediately imply that all operational countries are connected. Available data also shows that the level of connection is very different: while the Netherlands and Austria are connected to 23 countries, Bulgaria is exchanging DNA data with 9 countries and the UK with 1 country (EU Council, 2019). 


\section{PrÜM Modus OPERANDI}

Transnational DNA data exchange within the Prüm system works as follows: when a search is made in a national database for a DNA sample retrieved from a crime scene and no match is found, the Council Decision permits the data to be transmitted and searched in the national databases of other Member States (the so-called Step 1 of the Prüm system). A notification is then sent to the original Member State notifying it of a hit or the lack thereof. If a hit is identified, further requests for information are processed through the existing police or judicial channels (the so-called Step 2 of the Prüm system, which is governed by national law).

The EU regulation of the Prüm system stipulates that, for the purposes of supplying data, each Member State shall designate a National Contact Point (NCP), and the powers of the NCPs shall be governed by the applicable national law (Decision 2008/615/JHA). Different countries have attributed the custody of the national DNA databases to different entities, ranging from judicial authorities to police forces. In the great majority of countries involved in the Prüm system, the Ministry of the Interior (or Ministry of Internal Affairs or Ministry of Home Affairs) - a government ministry typically responsible for policing, emergency management, national security and immigration matters - has custody over the National Criminal DNA Database. The exceptions to this scenario are Belgium, the Netherlands, Portugal and Sweden, in which the Ministry of Justice has custody over the National DNA Database. The Ministry of Justice typically has specific duties associated with the organization of the justice system, overseeing public prosecutors and maintaining the legal system and public order. As a result of such a diversified context, the roles and responsibilities of Prüm NCPs may vary among countries, according to different organizational structures and national legislation.

The forensic practitioners acting as NCPs are central actors in the Prüm regime: they conduct the daily activities that enable transnational exchange and hold a crucial position in decision-making processes. In particular, the persons acting as NCPs must organize and implement the necessary procedures and connections to perform automated exchanges with other databases (both receiving and sending information), perform tests with partners in other countries as well as manage and report DNA matches. The NCPs in charge of complying with the technical standards for the exchange of DNA data information among Member States on a hit/nohit basis are officially called Step 1 NCPs. Typically, these NCPs are 
forensic experts working in forensic genetics laboratories. The NCPs in charge of the requests for additional information through mutual assistance procedures are called Step 2 NCPs and are usually professionals with relevant experience in police and judicial cooperation in transnational criminal investigations. Therefore, the Prüm regime brings together a wide range of professionals and a shifting set of relationships with data, technological infrastructures, operational procedures and criminal justice systems that support the circulation of information (M'charek, Hagendijk, \& de Vries, 2013).

\section{The Prüm Challenges}

The development of the Prüm system has received academic attention that might be summarized along two distinct lines of enquiry: on the one hand, a branch of literature that focuses on Prüm's societal, political and ethical challenges; on the other hand, a group of studies that aim to map the geographical patterns of cross-border crime and DNA data flows among the different EU Member States.

Within this first group of literature, it is clear that the ethical implications of the transnational exchange of forensic DNA data under the Prüm regime are paramount. The current academic debate highlights the ethical challenges related to data protection, the excessive surveillance of citizens and potential threats to civil rights such as privacy, liberty and the presumption of innocence (McCartney, 2010; McCartney et al., 2011; Nuffield Council on Bioethics, 2007). Additionally, several authors observed a democratic deficit when the Prüm Convention was transposed into EU acquis (Balzacq, 2005; Balzacq, Bigo, Carrera, \& Guild, 2006; Bellanova, 2017; Bigo, 2008). Such issues are compounded by the lack of systems to ensure transparency, accountability and trust, as well as ethical oversight of the transnational flow of law enforcement information (Hufnagel \& McCartney, 2015; McCartney, 2013, 2014a, 2014b; McCartney et al., 2011; Prainsack \& Toom, 2010, 2013). Victor Toom and his colleagues, when reviewing a decade of cross-border exchange and comparison of forensic DNA data, outline how their concerns over accountability and transparency posed at the time of the Prüm Decisions (EU Council, 2008a, 2008b) continue to be problematic, as quantitative and publicly available information that would make it possible to access DNA data exchange and comparison in the Prüm regime is limited, disjointed and largely unavailable (Toom, 2018; Toom et al., 2019). 
Another crucial topic of debate within regards the enormous disparities in national legislation across EU Member States. As previously noted in Chap. 5 , in the EU, there is considerable variation among national forensic DNA databases regarding the criteria for including profiles and the periods of time and conditions for their retention and/or deletion (Cho \& Sankar, 2004; Machado \& Silva, 2016; Santos, Machado, \& Silva, 2013; Van Camp \& Dierickx, 2007). Thereby, such a scenario draws attention to the inherent heterogeneities of the Prüm regime, by binding together diverse regulations regarding the collection and retention of forensic bioinformation (Prainsack \& Toom, 2013).

Barbara Prainsack and Victor Toom (2010) explored the situated dis/ empowerment of the Prüm system on the basis of three dimensions: data protection, new investigative epistemology and increasing investment on DNA technologies. In terms of data protection, the authors show that while Prüm might render a wide group of people into objects of surveillance, by working in a two-step approach, it might also reduce the amount of information that travels across borders. Such a decrease will, in principle, occur because personal data is only sent after a match has been confirmed, thus leading to a more targeted exchange. Prainsack and Toom (2010) also outline the forms whereby Prüm co-constructs a new investigative epistemology. By constituting DNA evidence in criminal investigations as central, a new configuration emerges in ways that shift power away from criminal investigators and towards forensic geneticists. Finally, the authors also explore how Prüm might, indeed, contribute to solving crimes in the EU (thus empowering citizens and victims) yet it might also divert attention and resources from other types of crime not directly involving biological evidence, such as human trafficking, fiscal crimes and child abuse (Prainsack \& Toom, 2010).

Some of these preliminary analyses have inspired recent empirically based studies on Prüm. One of such studies explores what "ethics" means to forensic practitioners actively involved in transnational DNA data exchanges under the Prüm system (Machado \& Granja, 2018). Based on interviews with Prüm NCPs, the authors demonstrate that such professionals face a wide variety of ethically significant issues. Participants highlighted that ethics are related to good scientific and laboratory practices, mentioned problems when receiving contaminated samples in the laboratory or reporting false positives to other countries, referred to data protection procedures and outlined efforts to address social accountability by producing reports for assessment by external authorities and/or use by 
the general public. Moreover, the authors found that NCPs created "ethical boundaries" between science/ethics, science/criminal justice systems and good/bad science that aimed to address and manage ethical controversies.

In another publication, Helena Machado and Rafaela Granja addressed the topic of how forensic DNA evidence is given meaning within the various ways of constructing a police epistemic culture within Prüm (Machado \& Granja, 2019a). Based on interviews with NCPs involved in international police cooperation, the authors show how the construction of a particular police epistemic culture is related to dynamics linked to the boundary work that creates, advocates and reinforces distinctions regarding other professionals also involved in transnational cooperation, such as the judicial authorities and forensic scientists. On the one hand, the judicial authorities are seen as a professional group that works mainly through formal procedures on a national or local level, while lacking the experience of international cooperation traditions. On the other hand, police professionals enact boundary work in relation to forensic scientists by outlining how the value of a DNA hit does not reside in the hit by itself but on the police work which can turn DNA data into DNA evidence. Hence, the Prüm system involves the interaction of various epistemic cultures and professional practices, entailing both cooperation and coordination, in addition to enacting the differences and divisions between the different social actors in the criminal justice system (Machado \& Granja, 2019a).

One other study by Helena Machado, Rafaela Granja and Nina Amelung analysed the fluid and flexible forms of constructing suspicion which take shape in transnational governance of crime through forensic DNA databases (Machado, Granja, \& Amelung, 2020). The authors demonstrate that, within the Prüm system, suspicion is constructed through forms of deterritorializing and reterritorializing assumptions about criminality linked to the movements of suspect communities across the EU. The deterritorialization of suspicion is configured in two ways. Firstly, it amplifies imaginaries of Europeanization that are linked to the increase in transnational collaboration in the area of crime control. Considering that the "free" mobility of citizens within the EU facilitates criminal activity across borders, NCPs conceive the emergence of the Prüm system as a logical outcome. The transnational exchange of DNA data is therefore seen as an opportunity to regain "control" over the coexisting mobility of noncriminal and criminal populations. Secondly, the deterritorialization of suspicion also involves incorporating depersonalization, neutrality and 
procedural objectivity into the operations of the automated and permanent DNA data exchange. Juxtaposed to that, the reterritorializing of suspicion operates through the continuous (re)creation of assertions concerning criminality and specific populations from certain East European countries. In this sense, the transnational exchange of DNA data in EU demonstrates how "new" forms of suspicion relate to the reinforcement of "old" criminal categories (Machado et al., 2020).

One last study conducted by Machado and Granja regards how NCPs perceive the risks and benefits of transnational exchange of forensic DNA data. The authors show that the perceived benefits relate to the intensification of tools for combating transnational criminality, development of standardization and harmonization of forensic DNA testing procedures and reinforcement of professional cooperation. The perceived risks are associated to the possibility that individuals may be prosecuted on the basis of false positives, the lack of available data to measure the effectiveness of the Prüm system and the different modus operandi of police forces and judicial authorities (Machado \& Granja, 2019b).

The second group of studies on the Prüm system have been assessing the geographical patterns of cross-border crimes solved by the exchange of DNA data among the different EU Member States (Bernasco, Lammers, \& Van der Beek, 2016; Taverne \& Broeders, 2015, 2016). One study suggested a territorial divide between Western and Central European countries and Eastern European countries. On the basis of an analysis of the official statistical data et of the Prüm system, this research revealed a trend amongst Western and Central European countries to accumulate the majority of DNA profiles of individuals originating from Eastern European countries (Santos \& Machado, 2017). In other words, the study showed how the geographical patterns of DNA flows between the EU Member States involved in the Prüm system appeared to confirm previous research about the patterns of criminal mobility affecting central European countries, which is mostly associated with volume crime usually involving individuals originating from Eastern Europe (Bernasco et al., 2016; Siegel, 2014; Van Daele, 2008).

\section{Concluding Remarks}

Taking into consideration the increasing shifts in several social life domains when collecting and processing massive amounts of data, this chapter articulates how, within contemporary projects that aim to know and 
govern mobile bodies (Aas, 2011; Broeders, 2007), the governance of crime takes place by managing several decisions related to the production, circulation and use of data. The transnational exchange of DNA data via the Prüm system represents a technological infrastructure designed to control transnational mobile populations through a dispersed network featuring an enhanced level of detection.

In addition to fostering a closer collaboration among police forces in the EU, the Prüm system also emerged as an additional driver of the panEuropean integration project by attempting to overcome cultural, political and socioeconomic disparities. It did so through a combination of technological standardization measures among countries and an ongoing emphasis on a prevalent discourse focusing on security and risk prevention (Prainsack \& Toom, 2013). Nevertheless, such a goal of overcoming disparities is paired with the consolidation of a system of wider social sorting that highlights several geopolitical tensions. In other words, since national DNA databases tend to reflect policing practices that usually target minorities, such as foreigners and/or ethnic minorities (Chow-White \& Duster, 2011; Duster, 2006; Skinner, 2013, 2018), by enabling the transnational exchange of data, the Prüm system has the power to reassert and extend the discriminatory power of DNA databases. The transnational exchange of DNA data in the EU thereby enables the (re)making of the connections between criminality and suspicious movements of data and of particular populations leaving specific national territories (Machado et al., 2020).

\section{REFERENCES}

Aas, K. F. (2011). "Crimmigrant" bodies and bona fide travelers: Surveillance, citizenship and global governance. Theoretical Criminology, 15(3), 331-346. https://doi.org/10.1177/1362480610396643

Aas, K. F. (2013). Globalization and crime. Vol. I-III. London: Sage.

Ajana, B. (2013). Governing through biometrics: The biopolitics of identity. London: Palgrave Macmillan.

Amoore, L. (2006). Biometric borders: Governing mobilities in the war on terror. Political Geography, 25(3), 336-351.

Balzacq, T. (2005). From a Prüm of 7 to a Prïm of 8 +: What are the implications? (No. IP/C/LIBE/FWC/2005-22). Policy Department C Citizens Rights and Constitutional Affairs. Brussels.

Balzacq, T., Bigo, D., Carrera, S., \& Guild, E. (2006). Security and the two-level game: The treaty of Prïm, the EU and the management of threats (No. 234). Retrieved from http://aei.pitt.edu/6678/ 
Bellanova, R. (2017). Digital, politics, and algorithms: Governing digital data through the lens of data protection. European Journal of Social Theory, 20(3), 329-347. https://doi.org/10.1177/1368431016679167

Bernasco, W., Lammers, M., \& Van der Beek, K. (2016). Cross-border crime patterns unveiled by exchange of DNA profiles in the European Union. Security Journal, 29(4), 640-660. https://doi.org/10.1057/sj.2015.27

Bigo, D. (2004). Criminalisation of 'migrants': The side effect of will to control the frontiers and sovereign illusion. In B. Bogusz, R. Cholewinski, A. Cygan \& E. Szyszczak (Eds.), Irregular migration and human rights: Theoretical, European and international perspectives (pp. 61-92). Martinus Nijhoff Publishers.

Bigo, D. (2005). Frontier controls in the European Union: Who is in control? In E. Guild (Ed.), Controlling frontiers: Free movement into and within Europe (1sted.,pp.49-99). Routledge.https://doi.org/10.4324/9781315259321-2

Bigo, D. (2008). EU police cooperation: National sovereignty framed by European security? In E. Guild \& F. Geyer (Eds.), Security versus justice? Police and judicial cooperation in the European Union (pp. 91-108). Aldershot: Ashgate.

Bigo, D., \& Guild, E. (2005). Policing in the name of freedom. In D. Bigo \& E. Guild (Eds.), Controlling frontiers: Free movement into and within Europe (pp. 1-13). Aldershot, Burlington: Ashgate.

Bosworth, M., \& Guild, M. (2008). Governing through migration control: Security and citizenship in Britain. British Journal of Criminology, 48(6), 703719. https://doi.org/10.1093/bjc/azn059

Broeders, D. (2007). The new digital borders of Europe: EU databases and the surveillance of irregular migrants. International Sociology, 22(1), 71-92. https://doi.org/10.1177/0268580907070126

Broeders, D., \& Dijstelbloem, H. (2016). The datafication of mobility and migration management: The mediating state. In I. Van der Ploeg \& J. Pridmore (Eds.), Digitizing identities: Doing identity in a networked world (pp. 242260). London: Routledge. https://doi.org/10.4324/9781315756400

Cho, M., \& Sankar, P. (2004). Forensic genetics and ethical, legal and social implications beyond the clinic. Nature Genetics, 36(11 Suppl), S8-S12. https://doi. org/10.1038/ngl594

Chow-White, P., \& Duster, T. (2011). Do health and forensic DNA databases increase racial disparities? PLoS Medicine, 8(10), el001100. https://doi. org/10.1371/journal.pmed.1001100

Council of the European Union. (2019). Implementation of the provisions on information exchange of the "Prïm Decisions". Brussels.

Duster, T. (2006). Explaining differential trust of DNA forensic technology: Grounded assessment or inexplicable paranoia? Journal of Law, Medicine \& Ethics, 34(2), 293-300.

EU Council. (2005). Prüm convention (Vol. 2005). Brussels, 7 July.

EU Council. Council Decision 2008/615/JHA of 23 June 2008 on the stepping up of cross-border cooperation, particularly in combating terrorism and cross- 
border crime, 2007 Official Journal of the European Union $\$$ (2008a). Official Journal of the European Union.

EU Council. Council Decision 2008/616/JHA of 23 June 2008 on the implementation of Decision 2008/615/JHA on the stepping up of cross-border cooperation, particularly in combating terrorism and cross-border crime, 2008 $\$(2008$ b). Official Journal of the European Union.

Guild, E., \& Geyer, F. (2008). Security versus Justice? Police and judicial cooperation in the European Union. Farnham, UK: Ashgate.

Hufnagel, S., \& McCartney, C. (2015). Police cooperation against transnational criminals. In N. Boister \& R. J. Currie (Eds.), Routledge handbook of transnational criminal law (pp. 107-120). Oxon and New York: Routledge.

Hufnagel, S., \& McCartney, C. (Eds.). (2017). Trust in international police and justice cooperation. Oxford: Hart Publishing.

Kuus, M. (2004). Europe's eastern expansion and the reinscription of otherness in East-Central Europe. Progress in Human Geography, 28, 472-489. https:// journals.sagepub.com/doi/10.1191/0309132504ph498oa

Luif, P. (2007). The treaty of Prüm: A replay of Schengen? In European Union Studies Association, Tenth biennial international conference. Montreal, Canada. Retrieved from http://aei.pitt.edu/id/eprint/7953

Lyon, D. (2007). Surveillance studies: An overview. Cambridge: Polity Press.

M'charek, A., Hagendijk, R., \& de Vries, W. (2013). Equal before the law: On the machinery of sameness in forensic DNA practice. Science, Technology, \& Human Values, 38(4), 542-565. https://doi.org/10.1177/0162243912453623

M'charek, A., Schramm, K., \& Skinner, D. (2014). Topologies of race: Doing territory, population and identity in Europe. Science, Technology, \& Human Values, 39(4), 468-487. https://doi.org/10.1177/0162243913509493

Machado, H., \& Granja, R. (2018). Ethics in transnational forensic DNA data exchange in the EU: Constructing boundaries and managing controversies. Science as Culture, 27(2), 242-264. https://doi.org/10.1080/09505431. 2018.1425385

Machado, H., \& Granja, R. (2019a). Police epistemic culture and boundary work with judicial authorities and forensic scientists: The case of transnational DNA data exchange in the EU. New Genetics and Society, 38(3), 289-307.

Machado, H., \& Granja, R. (2019b). Risks and benefits of transnational exchange of forensic DNA data in the EU: The views of professionals operating the Prüm system. Journal of Forensic and Legal Medicine, 68, 101872.

Machado, H., Granja, R., \& Amelung, N. (2020). Constructing suspicion through forensic DNA databases in the EU. The views of the Prüm professionals. The British Journal of Criminology, 60(1), 141-156. https://doi.org/10.1093/ bjc/azz057

Machado, H., \& Silva, S. (2016). Voluntary participation in forensic DNA databases: Altruism, resistance, and stigma. Science, Technology, \& Human Values, 41(2), 322-343. https://doi.org/10.1177/0162243915604723 
McCartney, C. (2010). Trans-national exchange of forensic (bio)information. In G. Bruinsma \& D. Weisburd (Eds.), Emerging issues in international forensic bioinformation exchange (pp. 1-27). University of Leeds, London, UK: Springer.

McCartney, C. (2013). Opting in and opting out: Doing the hokey cokey with EU policing and judicial cooperation. The Journal of Criminal Law, 77, 543-561. https://doi.org/10.1350/jcla.2013.77.6.879

McCartney, C. (2014a). Forensic data exchange: Ensuring integrity. Australian Journal of Forensic Sciences, 47(1), 36-48. https://doi.org/10.1080/004506 18.2014 .906654

McCartney, C. (2014b). Transnational exchange of forensic evidence. In G. Bruinsma \& D. Weisburd (Eds.), Encyclopedia of criminology and criminal justice (pp. 5302-5313). New York: Springer.

McCartney, C., Wilson, T., \& Williams, R. (2011). Transnational exchange of forensic DNA: Viability, legitimacy, and acceptability. European Journal on Criminal Policy and Research, 17(4), 305-322. https://doi.org/10.1007/ s10610-011-9154-y

Nuffield Council on Bioethics. (2007). The forensic use of bioinformation: Ethical issues. London. Retrieved from http://nuffieldbioethics.org/wp-content/ uploads/The-forensic-use-of-bioinformation-ethical-issues.pdf

Pickering, S., \& Weber, L. (2006). Borders, mobility and technologies of control. In S. Pickering \& L. Weber (Eds.), Borders, mobility and technologies of control (1st ed., pp. 1-19). Dordrecht: Springer Netherlands. https://doi. org/10.1007/1-4020-4899-8_1

Prainsack, B., \& Toom, V. (2010). The Prüm regime. Situated dis/empowerment in transnational DNA profile exchange. British Journal of Criminology, 50(6), 1117-1135. https://doi.org/10.1093/bjc/azq055

Prainsack, B., \& Toom, V. (2013). Performing the Union: The Prüm Decision and the European dream. Studies in History and Philosophy of Biological and Biomedical Sciences, 44(1), 71-79. https://doi.org/10.1016/j.shpsc.2012. 09.009

Santos, F., \& Machado, H. (2017). Patterns of exchange of forensic DNA data in the European Union through the Prüm system. Science \& Justice, 57(4), 307313. https://doi.org/10.1016/j.scijus.2017.04.001

Santos, F., Machado, H., \& Silva, S. (2013). Forensic DNA databases in European countries: Is size linked to performance? Life Sciences, Society and Policy, $9(12)$, 1-13. https://doi.org/10.1186/2195-7819-9-12

Siegel, D. (2014). Lithuanian itinerant gangs in the Netherlands. Kriminologijos Studijos, 2, 5-40. Retrieved from https://pdfs.semanticscholar.org/3f8e/ c9ba48b92eb423602a3852656122eb6d38ae.pdf

Skinner, D. (2013). "The NDNAD has no ability in itself to be discriminatory": Ethnicity and the governance of the UK National DNA Database. Sociology, 47(5), 976-992. https://doi.org/10.1177/0038038513493539

Skinner, D. (2018). Race, racism and identification in the era of technosecurity. Science as Culture, 1-23. https://doi.org/10.1080/09505431.2018.1523887 
Taverne, M., \& Broeders, A. P. A. (2015). The light's at the end of the funnel! Evaluating the effectiveness of the transnational exchange of DNA profiles between the Netherlands and other Prüm countries. Zutphen: Paris Legal Publishers.

Taverne, M., \& Broeders, A. P. A. (2016). Cross-border patterns in DNA matches between the Netherlands and Belgium. Science \& Justice, 57(1), 28-34. https://doi.org/10.1016/j.scijus.2016.08.008

Toom, V. (2018). Cross-border exchange and comparison of forensic DNA data in the context of the Prüm Decision. Civil Liberties, Justice and Home Affairs. Retrieved from http://www.europarl.europa.eu/thinktank/en/document. html?reference=IPOL_STU(2018)604971

Toom, V., Granja, R., \& Ludwig, A. (2019). The Prüm Decisions as an aspirational regime: Reviewing a decade of cross-border exchange and comparison of forensic DNA data. Forensic Science International: Genetics, 41, 50-57. https:// doi.org/10.1016/j.fsigen.2019.03.023

Töpfer, E. (2011). 'Network with errors': Europe's emerging web of DNA databases. State Watch Analysis, 21, 1-5.

Tutton, R., Hauskeller, C., \& Sturdy, S. (2014). Suspect technologies: Forensic testing of asylum seekers at the UK border. Ethnic and Racial Studies, 37(5), 738-752. https://doi.org/10.1080/01419870.2013.870667

Van Camp, N., \& Dierickx, K. (2007). National forensic databases: Social-ethical challenges \& current practices in the EU. Leuven: European Ethical-Legal Papers $\mathrm{n}^{\circ} 9$. Retrieved from http://www.academia.edu/attachments/ $6227872 /$ download_file

Van Daele, S. (2008). Organised property crimes in Belgium: The case of the 'itinerant crime groups'. Global Crime, 9, 241-247. Retrieved from https:// www.tandfonline.com/doi/abs/10.1080/17440570802254346?journa lCode $=$ fglc 20

Open Access This chapter is licensed under the terms of the Creative Commons Attribution 4.0 International License (http://creativecommons.org/licenses/ by $/ 4.0 /)$, which permits use, sharing, adaptation, distribution and reproduction in any medium or format, as long as you give appropriate credit to the original author(s) and the source, provide a link to the Creative Commons licence and indicate if changes were made.

The images or other third party material in this chapter are included in the chapter's Creative Commons licence, unless indicated otherwise in a credit line to the material. If material is not included in the chapter's Creative Commons licence and your intended use is not permitted by statutory regulation or exceeds the permitted use, you will need to obtain permission directly from the copyright holder.

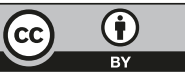

